\title{
GUN1 and Plastid RNA Metabolism: Learning from Genetics
}

\author{
Luca Tadini $+(\mathbb{D}$, Nicolaj Jeran $+(\mathbb{B}$ and Paolo Pesaresi *(i) \\ Department of Biosciences, University of Milan, 20133 Milan, Italy; luca.tadini@unimi.it (L.T.); \\ nicolaj.jeran@unimi.it (N.J.) \\ * Correspondence: paolo.pesaresi@unimi.it; Tel.: +39-02503-15057 \\ t These authors contributed equally to the manuscript.
}

Received: 29 September 2020; Accepted: 14 October 2020; Published: 16 October 2020

\begin{abstract}
GUN1 (genomes uncoupled 1), a chloroplast-localized pentatricopeptide repeat (PPR) protein with a C-terminal small mutS-related (SMR) domain, plays a central role in the retrograde communication of chloroplasts with the nucleus. This flow of information is required for the coordinated expression of plastid and nuclear genes, and it is essential for the correct development and functioning of chloroplasts. Multiple genetic and biochemical findings indicate that GUN1 is important for protein homeostasis in the chloroplast; however, a clear and unified view of GUN1's role in the chloroplast is still missing. Recently, GUN1 has been reported to modulate the activity of the nucleus-encoded plastid RNA polymerase (NEP) and modulate editing of plastid RNAs upon activation of retrograde communication, revealing a major role of GUN1 in plastid RNA metabolism. In this opinion article, we discuss the recently identified links between plastid RNA metabolism and retrograde signaling by providing a new and extended concept of GUN1 activity, which integrates the multitude of functional genetic interactions reported over the last decade with its primary role in plastid transcription and transcript editing.
\end{abstract}

Keywords: GUN1; RNA polymerase; transcript accumulation; transcript editing; retrograde signaling

\section{Introduction}

The GUN1 (genomes uncoupled 1) protein is a pentatricopeptide repeat (PPR)-containing protein that localizes to plastids and relays signals to the nucleus after exposure to either norflurazon (NF) or lincomycin (Lin) treatment [1,2]. Although these inhibitors block distinctly different processes-NF inhibits carotenoid biosynthesis by non-competitively binding to phytoene desaturase [3], while Lin is a plastid-specific inhibitor of $70 S$ ribosomes and plastid translation [4] - both drug treatments have been shown to reduce levels of plastid transcripts, indicating that a GUN1-dependent pathway is triggered by perturbation of transcription in the plastids [5]. The involvement of plastid transcription in signaling to the nucleus was initially deduced from the observation that treatment of barley seedlings with tagetitoxin, an inhibitor of the plastid-encoded RNA polymerase (PEP; [6]), decreased transcription of members of the nuclear $R b c S$ and $L h c b 1$ gene families, without altering plastid DNA replication [7]. Later studies have shown that loss of sigma factor 2 (SIG2) or 6 (SIG6) - each of which is utilized by the PEP to transcribe specific sets of plastid genes [8-10] —also activates retrograde signaling [11]. The fact that nuclear gene expression is restored in sig 2 gun 1 and sig6 gun1 double mutants has provided further support for the key role of plastid transcription in triggering a GUN1-dependent retrograde response [11].

Here, we propose a new model for GUN1 function in plastids and GUN1-mediated retrograde communication, which integrates the interactions observed between GUN1 and the machinery that controls plastid protein homeostasis with the recently discovered role of GUN1 in plastid RNA metabolism [12-16]. The many additive phenotypic effects and the very few suppressor phenotypes 
observed in higher-order (compound) mutants containing gun1 together with mutations affecting various aspects of plastid protein homeostasis, sugar sensing, and plastid osmosis can all be interpreted as pleiotropic phenotypic effects of a primary alteration in plastid transcription and plastid transcript editing attributable to the lack of the GUN1 protein under conditions that would otherwise trigger plastid-to-nucleus retrograde communication.

\section{GUN1 and the " $\Delta-r p o$ Phenotype"}

GUN1 does not appear to bind directly to RNAs [17], unlike typical PPR proteins [17]. But it is targeted to an organelle, the chloroplast, and has recently been reported by two independent laboratories to influence plastid transcript accumulation [13-15]. In particular, following perturbation of PEP activity, a peculiar pattern of plastid transcription, designated as the " $\Delta$-rpo phenotype", is typically observed in different plant species [14,18-20]. For example, Arabidopsis seedlings lacking proteins required for PEP-mediated transcription and regulation, such as sigma factors (sig6; [21]), PEP-associated proteins (pap2 and pap8; [22]), and the plastid redox insensitive 2 (prin2) protein [23,24], show a decrease in the expression of genes, coding for subunits of the photosynthetic apparatus ( $p e t B, p s a B, p s b A, p s b B, p s b C, p s b D, r b c L$ ), which are normally transcribed by PEP (see Figure 1). Conversely, the expression levels of nucleus-encoded RNA polymerase (NEP)-dependent transcripts of genes, encoding the core subunits of the PEP enzymes $(r p o A, r p o B, r p o C 1)$, ribosomal subunits ( $r p s 2$ and rps15), ycf1 (translocon at inner envelope membrane of chloroplasts 214), and clpP1 (a subunit of the 350-kDa chloroplast Clp complex), increase significantly (Figure 1). A similar plastid gene expression pattern is observed in seedlings impaired in plastid transcript maturation ( $p d m 1 ;$ [25]) and in seedlings grown in the presence of Lin (Col-0 + Lin) or altered in plastid protein synthesis by depletion of plastid ribosomal proteins [14]. Strikingly, gun1 cotyledons have shown a limited increase in the accumulation of NEP-dependent transcripts when grown in the presence of Lin (gun1 + Lin, [14]; see also Figure 1) and when the gun1 mutation is introgressed into genetic backgrounds lacking plastid ribosomal subunits [14]. Furthermore, the same set of NEP-dependent transcripts is highly downregulated after treatment of gun1 seedlings with NF (gun1 + NF), but their levels do not exhibit major changes in Col-0 + NF and gun $5+$ NF seedlings, implying a specific role for GUN1 in NEP-dependent transcript accumulation (Figure 1). Recently, a similar observation has been reported based on a comparison of the plastid gene expression profiles of cue8 (chlorophyll a/b-binding protein-underexpressed 8 ) and cue8 gun 1 mutants: i.e., the " $\Delta$-rpo phenotype" characteristic of cue 8 seedlings is almost completely abolished in cue8 gun1 cotyledons [13].

The " $\Delta$-rpo phenotype" is thought to be part of the regulatory mechanisms that serve to modulate the activities of NEP and PEP enzymes during plastid differentiation and in the course of responses of mature chloroplasts to environmental cues [27,29-31]. The physical interaction of GUN1 with $\mathrm{NEP}$, as revealed by co-immunoprecipitation studies and bimolecular fluorescence complementation (BiFC) assays [14], seems to lie at the basis of the GUN1-mediated accumulation of NEP-dependent plastid transcripts following activation of retrograde communication, possibly favored by decreased competition for template binding and/or increased availability of dNTPs. As an alternative explanation, Loudya et al. proposed that GUN1 sustained chloroplast DNA (cpDNA) replication under specific conditions, as demonstrated by copy numbers of cpDNA, which were reduced by half in cue 8 gun 1 chloroplasts with respect to the single mutants and wild-type plants [13]. 


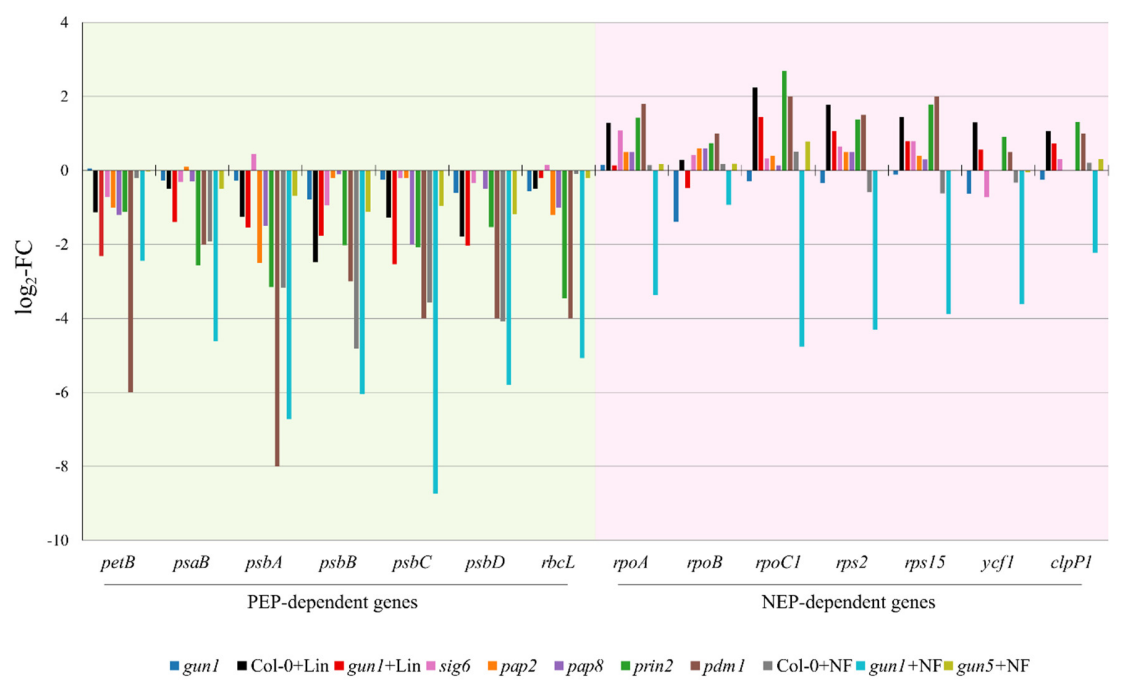

Figure 1. Expression analyses of a subset of PEP- and NEP-dependent plastid genes in different genetic backgrounds and after treatments that alter PEP activity. Values are expressed as the logarithm of the fold-change ( $\log _{2}-\mathrm{FC}$ ) relative to wild-type seedlings grown under optimal conditions. Data are retrieved from the literature in the case of sig6 [26], pap2 and pap8 [27], prin2 [23], and pdm1 (pigment-deficient mutant 1) [28] and from the GEO public repository in the case of gun1, Col-0 + Lin, gun1 + Lin (GEO accession GSE5770; [2]), Col-0 + NF, gun1 + NF, and gun5 + NF (GEO accession GSE12887;[2]). Lincomycin treatment of wild-type Arabidopsis seedlings (Col-0 + Lin) leads to a drop in PEP-dependent transcript accumulation. As an adaptive response, NEP-dependent transcript levels are increased in plastids, giving rise to what is known as the " $\Delta$-rpo phenotype". Similar behavior is observed in mutants, such as sig6, pap2, pap8, prin2, and pdm1, which lack either nucleus-encoded plastid proteins required for PEP activity (SIG6, PAP2, PAP8, PRIN2) or mRNA maturation factors (PDM1). However, gun1 seedlings grown in the presence of lincomycin $(g u n 1+$ Lin) show an impaired " $\Delta$-rpo phenotype": i.e., NEP-dependent transcripts show a very limited degree of upregulation. Similarly to lincomycin, gun1 seedlings grown on norflurazon-containing medium (gun1 + NF) undergo severe repression of PEP-dependent genes, and repression is even more pronounced if NEP-dependent transcripts are considered. On the contrary, Col-0 and gun5 (genomes uncoupled 5) seedlings in the presence of norflurazon (Col-0 + NF and gun5 + NF) show a wild-type-like plastid gene expression, indicating that the drastically reduced accumulation of PEP- and NEP-dependent transcripts upon NF treatment is a characteristic of the gun1 genetic background.

\section{GUN1 and Plastid RNA Editing}

Like several other PPR proteins (for a review, see [32]), GUN1 has also been reported to influence plastid RNA editing [12], i.e., the enzymatic conversion of specific cytidines (Cs) to uridines (Us) in mRNAs, such that the information in mature RNAs deviates from that encoded in the plastid genome. The link between plastid retrograde signaling and plastid RNA editing was initially reported by Kakizaki et al. [33]. The authors demonstrated that RNA editing in plastids was indeed affected under conditions, such as Lin and NF treatments, that triggered plastid-to-nucleus signaling. In particular, reduced RNA editing levels were observed in rps14 transcripts and RNAs encoding NAD(P) dehydrogenase (NDH) subunits when Arabidopsis seedlings were treated with either of these drugs. However, direct evidence for a causal relationship between altered RNA editing and plastid signaling was lacking, and the proteins involved remained unknown. This issue has now been clarified by the recent demonstration that GUN1 interacts with an essential component of the plant RNA editosome-multiple organellar RNA editing factor 2 (MORF2) — and affects the editing of multiple plastid RNA sites during retrograde signaling. In particular, gun1 seedlings treated with NF affect the RNA editing levels at 11 sites in plastids, indicating the high specificity of GUN1 for target RNAs. Intriguingly, all the edited sites are in NEP-dependent transcripts encoding subunits of the ATP-dependent Clp protease, the NDH 
complex, the ribosomes, photosystem II, and core subunits of PEP. Furthermore, treatment of gun1 mutants with either NF or Lin leads to similarly increased RNA editing levels only at the rps $12-i-58$ site, while comparable decreases are observed for $r p o C 1-488$, psbZ-50, and rpoB-551 editing sites [12]. RNA editing is usually associated with amino-acid substitutions in protein-coding sequences or is used to create start/stop codons, thus serving as a correction mechanism for otherwise defective transcripts. As a matter of fact, mutants with altered RNA editing in plant organelles exhibit defects in development and growth, including pale and albino phenotypes [34-37]. In this specific case, GUN1 is responsible for the exchange of three highly conserved amino-acid residues in the $\beta$ subunit of the PEP core, known to be the catalytic site of the enzyme, and one in the rpoC1-encoded $\beta^{\prime}$ subunit, also part of the PEP core but with unknown function. Therefore, it is tempting to hypothesize that changes in RNA editing levels for $r p o B$ and $r p o C 1$ ultimately affect the activity of PEP. This, together with the impairment of GUN1-dependent regulation of NEP activity, might be the primary cause of the altered plastid transcript accumulation patterns observed in gun 1 cotyledons upon NF- or Lin-based stimulation of plastid communication with the nucleus ([14]; see also Figure 1).

\section{Genetic Evidence for GUN1's Interactions with the Plastid Protein Homeostasis Machinery}

Genetic evidence indicates that GUN1 plays an essential role during the early stages of chloroplast development in response to functional impairment of plastid gene expression, plastid protein import, plastid protein degradation, sugar sensing, or maintenance of plastid osmosis (see Tables 1 and 2 for details). This notion is based on the additive phenotypic effects observed when the gun 1 mutation is introgressed by manual crosses into genetic backgrounds, exhibiting defects in plastid transcription, transcript maturation and editing, plastid protein synthesis, import or degradation, or sugar sensing. Among the 31 gun1-containing higher-order mutants listed in Tables 1 and 2, 20 are characterized by additive phenotypic effects with respect to the single mutants (see also Figure 2). These include viable pale-green plants with reduced growth and photosynthetic performance, albino seedlings unable to grow autotrophically, and one embryo-lethal combination. These enhanced phenotypes, leading in some cases to non-viable double mutants, reveal the importance of GUN1 function in the plastid. They confirm that GUN1 activity indeed supports plant development by optimizing chloroplast biogenesis-and hence photosynthetic efficiency—even when plastid gene expression is impaired by genetic modifications.

Table 1. Visible phenotypic characteristics of Arabidopsis mutants altered in plastid protein homeostasis and crossed with gun1. Arabidopsis mutants affected in plastid transcription, plastid transcript maturation and editing, plastid translation, plastid protein import, and plastid protein degradation have been crossed manually with different gun1 alleles, including gun1-1 ${ }^{\mathrm{a}}$, gun1-9 ${ }^{\mathrm{b}}$, gun1-101 $^{\mathrm{c}}$, gun1-102 $^{\mathrm{d}}$, gun1-103e. The phenotypic characteristics of single and higher-order mutants, together with the existence of physical interactions between the corresponding proteins with GUN1, are reported. Superscript a-e letters specify the gun1 alleles introgressed in the different mutant backgrounds reported in the Table.

\begin{tabular}{|c|c|c|c|c|c|c|}
\hline Locus & Function & $\begin{array}{l}\text { Single Mutant Name and } \\
\text { Phenotype }\end{array}$ & Double Mutant Phenotype & $\begin{array}{l}\text { Additive (A) } \\
\text { or Suppressor } \\
\text { (S) Effect }\end{array}$ & $\begin{array}{l}\text { Physical } \\
\text { Interaction }\end{array}$ & Ref. \\
\hline \multicolumn{7}{|c|}{ Plastid Transcription } \\
\hline At2g24120 & $\begin{array}{l}\text { NEP: Nucleus- encoded } \\
\text { RNA polymerase }\end{array}$ & $\begin{array}{l}\text { sca3-1 }{ }^{\mathrm{d}} \text { : pale cotyledons; } \\
\text { reduced growth }\end{array}$ & albino-seedling lethal & A & Yes & [14] \\
\hline At1g08540 & $\begin{array}{l}\text { SIG2: determines PEP } \\
\text { promoter specificity }\end{array}$ & $\begin{array}{l}\text { sig2-2 }{ }^{\mathrm{b}} \text { : pale cotyledons; } \\
\text { reduced growth }\end{array}$ & $\begin{array}{l}\text { paler green/yellow cotyledons } \\
\text { and young leaves }\end{array}$ & A & No & [11] \\
\hline At2g36990 & $\begin{array}{l}\text { SIG6: determines PEP } \\
\text { promoter specificity }\end{array}$ & sig6- $\mathrm{I}^{\mathrm{b}}$ : identical to $\mathrm{WT}$ & yellow/white cotyledons & A & No & [11] \\
\hline At3g18420 & $\begin{array}{l}\text { SG1: chloroplast-localized, } \\
\text { tetratricopeptide } \\
\text { repeat-containing protein } \\
\text { required for chloroplast } \\
\text { development; involved in the } \\
\text { regulation of plastid } \\
\text { gene expression }\end{array}$ & $\begin{array}{l}s g 1^{\text {a }}: \text { slow green1-newly } \\
\text { formed albino leaves } \\
\text { gradually turn pale-green } \\
\text { and are fully green at } 3 \\
\text { weeks after germination; } \\
\text { reduced growth }\end{array}$ & $\begin{array}{l}\text { the delayed-greening } \\
\text { phenotype of the sg1 single } \\
\text { mutant is alleviated; } \\
\text { leaves of } s g 1 \text { gun1 are of similar } \\
\text { green color to the leaves } \\
\text { of WT plants }\end{array}$ & S & No & [38] \\
\hline At1g10522 & PRIN2: regulates PEP activity & $\begin{array}{l}\text { prin2-1 } 1^{\mathrm{a}}: \text { yellow/white } \\
\text { cotyledons; reduced growth }\end{array}$ & $\begin{array}{l}\text { identical to prin2-1 } \\
\text { single mutant }\end{array}$ & No effect & No & [23] \\
\hline
\end{tabular}


Table 1. Cont.

\begin{tabular}{|c|c|c|c|c|c|c|}
\hline Locus & Function & $\begin{array}{l}\text { Single Mutant Name and } \\
\text { Phenotype }\end{array}$ & Double Mutant Phenotype & $\begin{array}{l}\text { Additive (A) } \\
\text { or Suppressor } \\
\text { (S) Effect }\end{array}$ & $\begin{array}{l}\text { Physical } \\
\text { Interaction }\end{array}$ & Ref. \\
\hline \multicolumn{7}{|c|}{ Plastid Transcript Maturation/Editing } \\
\hline At3g03710 & $\begin{array}{c}\text { RIF10: } \\
\text { exoribonuclease-processing of } \\
\text { plastid RNA }\end{array}$ & $\begin{array}{l}\text { rif10-2 } 2^{\mathrm{c}} \text { : green cotyledons } \\
\text { and pale true leaves; } \\
\text { reduced growth }\end{array}$ & albino-seedling lethal & A & No & [39] \\
\hline At3g57180 & $\begin{array}{c}\text { BPG2: } \\
\text { regulates ribosomal } \\
\text { RNA maturation }\end{array}$ & $\begin{array}{l}b p g 2-2^{c}: \text { pale green/yellow } \\
\text { cotyledons }\end{array}$ & $\begin{array}{l}\text { identical to } b p g 2-2 \\
\text { single mutant }\end{array}$ & No effect & No & [40] \\
\hline At3g06980 & $\begin{array}{l}\text { RH50: modulates RNA } \\
\text { secondary structure }\end{array}$ & $r h 50-1^{\text {d: }}$ identical to WT & $\begin{array}{l}\text { marked reduction of } \\
\text { growth rate }\end{array}$ & A & No & [41] \\
\hline At4g02990 & $\begin{array}{l}\text { mTERF4: processing of } \\
\text { plastid transcripts }\end{array}$ & $\begin{array}{l}\text { coe } 1 / m_{\text {terff }} \mathrm{e} \text { : pale-yellow } \\
\text { cotyledons and leaves; } \\
\text { reduced growth }\end{array}$ & $\begin{array}{l}\text { more severe pale-yellow } \\
\text { phenotype; reduced growth }\end{array}$ & A & No & [42] \\
\hline At1g32990 & $\begin{array}{l}\text { PRPL11: plastid ribosomal } \\
\text { protein L11 }\end{array}$ & $\begin{array}{l}\text { prpl11-1 } 1^{\mathrm{d}} \text { : pale-green } \\
\text { cotyledons and leaves; } \\
\text { reduced growth }\end{array}$ & albino-seedling lethal & A & No & [17] \\
\hline At5g30510 & $\begin{array}{l}\text { PRPS1: plastid ribosomal } \\
\text { protein S1 }\end{array}$ & $\begin{array}{l}\text { prps1-1 } 1^{\mathrm{d}}: \text { pale green } \\
\text { cotyledons and leaves; } \\
\text { reduced growth }\end{array}$ & $\begin{array}{l}\text { less severe pale cotyledons and } \\
\text { leaves; increased growth }\end{array}$ & S & Yes & [17] \\
\hline At3g27160 & $\begin{array}{l}\text { PRPS21: plastid ribosomal } \\
\text { protein S21 }\end{array}$ & $\begin{array}{l}\text { prps } 21-1^{\mathrm{d}} \text { : pale green } \\
\text { cotyledons and leaves; } \\
\text { reduced growth }\end{array}$ & $\begin{array}{l}\text { identical to } p r p s 21-1 \\
\text { single mutant }\end{array}$ & No effect & No & [17] \\
\hline At5g16620 & $\begin{array}{l}\text { Tic40: subunit of the plastid } \\
\text { protein import apparatus }\end{array}$ & $\begin{array}{l}\text { tic } 40-4^{c}: \text { pale-green } \\
\text { cotyledons and leaves; } \\
\text { reduced growth }\end{array}$ & embryo-lethal & A & No & [44] \\
\hline At4g02510 & $\begin{array}{l}\text { Toc159: plastid protein } \\
\text { import receptor }\end{array}$ & $\begin{array}{l}\text { ppi2-2 } 2^{\mathrm{c}}: \text { albino-seedling } \\
\text { lethal }\end{array}$ & embryo-lethal & A & No & [33] \\
\hline At4g24280 & $\begin{array}{l}\text { cpHSC70-1: plastid protein } \\
\text { import and folding }\end{array}$ & $\begin{array}{l}\text { cphsc70-1 } 1^{\mathrm{c}, \mathrm{d}}: \text { altered } \\
\text { cotyledon and leaf shape; } \\
\text { slight variegation }\end{array}$ & $\begin{array}{l}\text { much smaller cotyledons; } \\
\text { larger variegation; } \\
\text { reduced growth }\end{array}$ & A & Yes & {$[14,44]$} \\
\hline At5g50920 & $\begin{array}{l}\text { CLPC1: protein import into } \\
\text { chloroplast stroma }\end{array}$ & $\begin{array}{l}c l p c 1-1^{c}: \text { pale-green } \\
\text { cotyledons and leaves; } \\
\text { reduced growth }\end{array}$ & $\begin{array}{l}\text { reduced photosynthetic } \\
\text { performance; reduced growth }\end{array}$ & A & Yes & {$[44]$} \\
\hline \multicolumn{7}{|c|}{ Plastid Protein Degradation } \\
\hline At1g50250 & $\begin{array}{l}\text { FTSH1: subunit of the } \\
\text { thylakoid-associated } \\
\text { heteromeric FTSH protease }\end{array}$ & $\begin{array}{l}\text { ftsh1-1 } 1^{\mathrm{d}} \text { : cotyledons } \\
\text { identical to WT }\end{array}$ & $\begin{array}{l}\text { identical to } f t s h 1-1 \\
\text { single mutant }\end{array}$ & No effect & No & [14] \\
\hline At2g30950 & $\begin{array}{l}\text { FTSH2: subunit of the } \\
\text { thylakoid-associated } \\
\text { heteromeric FTSH protease }\end{array}$ & $\begin{array}{c}\text { ftsh2-3 } 3^{\mathrm{b}} \text { : pale-green and } \\
\text { small cotyledons, } \\
\text { reduced growth }\end{array}$ & albino-seedling lethal & A & No & [14] \\
\hline At5g42270 & $\begin{array}{l}\text { FTSH5: subunit of the } \\
\text { thylakoid-associated } \\
\text { heteromeric FTSH protease }\end{array}$ & $\begin{array}{l}\text { ftsh5-3 } 3^{\mathrm{d}} \text { : cotyledons } \\
\text { identical to WT }\end{array}$ & severely variegated cotyledons & A & No & [14] \\
\hline At1g06430 & $\begin{array}{l}\text { FTSH8: subunit of the } \\
\text { thylakoid-associated } \\
\text { heteromeric FTSH protease }\end{array}$ & $\begin{array}{l}\text { ftsh8-1 } 1^{\text {d }} \text { cotyledons } \\
\text { identical to WT }\end{array}$ & $\begin{array}{l}\text { identical to } f t s h 8-1 \\
\text { single mutant }\end{array}$ & No effect & No & [14] \\
\hline
\end{tabular}

RIF10, resistant to inhibition with fosmidomycin 10; mTERF4, mitochondrial transcription termination factor 4; FUG1, fu-gaeri1; Tic40, translocon at the inner envelope membrane of chloroplasts; Toc159, translocon at the outer envelope membrane of chloroplasts; cpHSC70-1, chloroplast heat shock protein 70-1; CLPC1, caseinolytic protease complex component C1; CLPR1, caseinolytic protease complex component R1; FTSH, filamentation temperature sensitive metalloprotease. 
In eight genetic backgrounds, the gun1 mutation does not exacerbate the original mutant phenotype. The lack of any additive effect in gun $1 \mathrm{ftsh} 1-1$ and gun $1 \mathrm{ftsh} 8-1$ cotyledons and leaves can be ascribed to the fact that defective FtsH1 can be complemented by the major FtsH5 (type A) subunit, while FtsH8 can be replaced by the major FtsH2 (type B) subunit of the heteromeric filamentation temperature-sensitive (FtsH) metalloprotease associated with thylakoids (for a review, see [45]). Indeed, unlike ftsh 2 and ftsh 5, single ftsh1-1 and ftsh8-1 mutants do not display any visible phenotype [14], indicating that lack of either product does not perturb the activity of the FtsH metalloprotease. This can explain why GUN1-mediated retrograde signaling is not required in ftsh1-1 or ftsh8-1. Moreover, no additive effects are observed when the gun1 mutation is combined with gun2, gun4, and gun5 single mutants [46,47]. Indeed, the double mutants gun1 gun2, gun1 gun4, and gun1 gun5 accumulate chlorophylls to very similar levels and display growth rates comparable to those of gun2, gun4, and gun5 single mutants (see Table 2). Conversely, gun 2 gun 4 and gun 4 gun 5 double mutants are characterized by a more extreme chlorophyll phenotype than that of the corresponding single mutants. The exacerbation of the single mutant phenotype is even more prominent in gun 2 gun 5 , in which chlorophyll is undetectable $[46,47]$. Overall, these functional interactions allow us to exclude a major role for GUN1 in the tetrapyrrole biosynthetic pathway, which provides chlorophylls and other tetrapyrrole end-products, such as heme, siroheme, and phytochromobilin.

On the other hand, gun1 prin2-1, gun1 bpg2-2, and gun1 prps21-1 double mutants are also indistinguishable from the visible phenotypes of plastid redox insensitive 2-1 (prin2-1; [23]), brassinazole insensitive pale green 2-2 (bpg2-2; [40]), and plastid ribosomal protein s21-1 (prps21-1; [17]), respectively. In particular, comparison of prps21-1 with gun1 prps21-1 mutants seems to support the existence of an 'impairment threshold' in plastid gene expression, below which the activity of GUN1 is not required, or at the least, GUN1 activity is so low that its complete loss does not exacerbate the corresponding double mutant phenotypes. As a matter of fact, the prps21-1 single mutant accumulates more PEP-dependent $(r b c L$ and $p s b A)$ and NEP-dependent ( $r p o A$ and $\left.r p l 12-3^{\prime}\right)$ transcripts than the prpl11-1 single mutant [14], possibly explaining the marked difference between the albino-lethal phenotype of gun1 prpl11-1 seedlings and the pale-green phenotype of gun1 prps21-1 plants.

Only in three cases, gun1-containing higher-order mutants display an attenuated (suppressor) phenotype with respect to single mutants. For instance, the callus tissue formation observed in the shoot apex of the msl2 msl3 double mutant is suppressed in the gun $1 \mathrm{msl} / 2 \mathrm{msl} 3$ triple mutant, which results in the formation of green and normally shaped true leaves. Clearly, this genetic interaction highlights a major role of GUN1 protein in chloroplast biogenesis during the switch from leaf cell proliferation to expansion and differentiation [48]. The direct involvement of GUN1 in chloroplast biogenesis and, as a consequence, in cotyledon and leaf greening is further supported by the suppression in the gun 1 sg1 double mutant of the delayed-greening phenotype seen in sg1 plants, which is itself characterized by newly formed albino leaves that gradually turn green and become fully green by 3 weeks after germination ([38]; see also Table 1). Similarly, the gun1 prps1-1 double mutant shows less severe bleaching of cotyledons and leaves and increased photosynthetic performance and growth with respect to the prps1-1 single mutant due to GUN1-dependent control of the accumulation of the plastid ribosomal protein S1 (PRPS1; [17]). 
Table 2. Visible phenotypic characteristics of Arabidopsis mutants altered in tetrapyrrole biosynthesis and other functions and crossed with gun1. Arabidopsis mutants affected in tetrapyrrole biosynthesis, plastid osmosis, sugar metabolism, and plastid gene expression are crossed manually with different gun1 alleles, including gun1-1 ${ }^{\mathrm{a}}$, gun1- $9^{\mathrm{b}}$, gun1-101 ${ }^{\mathrm{c}}$. The phenotypic characteristics of single and higher-order mutants, together with the existence of physical interactions between the corresponding proteins with GUN1, are reported. Superscript a-c letters specify the gun1 alleles introgressed in the different mutant backgrounds reported in the Table.

\begin{tabular}{|c|c|c|c|c|c|c|}
\hline Locus & Function & $\begin{array}{l}\text { Single Mutant Name } \\
\text { and Phenotype }\end{array}$ & $\begin{array}{l}\text { Double Mutant } \\
\text { Phenotype }\end{array}$ & $\begin{array}{l}\text { Additive (A), } \\
\text { Suppressor } \\
\text { (S) Effect }\end{array}$ & $\begin{array}{l}\text { Physical } \\
\text { Interaction }\end{array}$ & Ref. \\
\hline \multicolumn{7}{|c|}{ Tetrapyrrole Biosynthesis } \\
\hline At2g26670 & GUN2: heme oxygenase & $\begin{array}{l}\text { gun } 2^{\mathrm{a}} \text { : long hypocotyl; } \\
\text { pale green cotyledons; } \\
\text { reduced growth }\end{array}$ & identical to gun2 & No effect & No & [46] \\
\hline At3g59400 & $\begin{array}{l}\text { GUN4: regulates } \\
\text { Mg-chelatase }\end{array}$ & $\begin{array}{l}\text { gun } 4^{\mathrm{a}} \text { : pale green } \\
\text { cotyeldons and leves; } \\
\text { reduced growth }\end{array}$ & identical to gun4 & No effect & No & [47] \\
\hline At5g13630 & $\begin{array}{l}\text { GUN5: ChlH subunit of } \\
\text { Mg-chelatase }\end{array}$ & $\begin{array}{l}\text { gun } 5^{\mathrm{a}}: \text { pale green } \\
\text { cotyledons and leaves; } \\
\text { reduced growth }\end{array}$ & identical to gun5 & No effect & No & [47] \\
\hline \multicolumn{7}{|c|}{ Other Plastid Functions } \\
\hline $\begin{array}{l}\text { At5g10490; } \\
\text { At1g58200 }\end{array}$ & $\begin{array}{l}\text { MSL2 and MSL3: two } \\
\text { members of the } \\
\text { MscS-like family of } \\
\text { mechanosensitive ion } \\
\text { channels. They are } \\
\text { localized in the plastid } \\
\text { envelope and are } \\
\text { required for normal } \\
\text { plastid size and shape }\end{array}$ & $\begin{array}{l}m s l 2 m s l 3^{\mathrm{b}} \text { : enlarged } \\
\text { and deformed plastids } \\
\text { in the shoot apical } \\
\text { meristem; develop a } \\
\text { mass of callus tissue at } \\
\text { the shoot apex }\end{array}$ & $\begin{array}{l}\text { abolished callus } \\
\text { formation at the shoot } \\
\text { apex; larger, greener, } \\
\text { and more normally } \\
\text { shaped true leaves }\end{array}$ & $\mathrm{S}$ & No & [48] \\
\hline At5g22510 & $\begin{array}{l}\text { INV-E: a } \\
\text { chloroplast-targeted } \\
\text { alkaline/neutral } \\
\text { invertase that is } \\
\text { implicated in the } \\
\text { development of the } \\
\text { photosynthetic } \\
\text { apparatus }\end{array}$ & $\begin{array}{l}\text { sicy-192 } \text { : sugar-inducible } \\
\text { cotyledon yellow-192 } \\
\text { mutant: yellow } \\
\text { cotyledons upon } \\
\text { treatment with sucrose; } \\
\text { gain of function mutant } \\
\text { of plastid invertase }\end{array}$ & $\begin{array}{l}\text { enhanced cotyledon } \\
\text { phenotype due to a } \\
\text { further decrease of } \\
\text { chlorophyll content }\end{array}$ & A & No & [49] \\
\hline At1g31410 & $\begin{array}{c}\text { ENF2: a } \\
\text { chloroplast-targeted } \\
\text { protein similar to } \\
\text { bacterial polyamine } \\
\text { transporters; important } \\
\text { for plastid } \\
\text { gene expression }\end{array}$ & $\begin{array}{c}\text { enf2- } 1^{\mathrm{a}} \text { : enlarged fil } \\
\text { expression domain } 2 \\
\text { mutant-mature leaves } \\
\text { are pale green, more } \\
\text { serrated, and narrower } \\
\text { than WT; in less than } 1 \% \\
\text { of cases, enf } 2-1 \text { forms } \\
\text { needle-like leaves; } \\
\text { chloroplast } \\
\text { development is delayed }\end{array}$ & albino-seedling lethal & A & No & {$[50]$} \\
\hline
\end{tabular}

\section{GUN1: A Major Checkpoint for the Control of Developmental Defects during Chloroplast Biogenesis and Mitigation of the Deleterious Effects of Stress}

GUN1 is a very low-abundance protein with a very short half-life and has never been detected in analyses of the plastid proteome. However, its stability and amount increase upon activation of retrograde signaling, as a consequence of the reduction/inhibition of Clp protease activity [51]. Nevertheless, it is reasonable to assume that even under conditions that activate the retrograde signaling pathway(s), GUN1 is unlikely to have a direct regulatory effect on the many highly abundant proteins that make up the plastid protein homeostasis machinery. A more realistic view suggests that most of the genetic interactions observed in the last decade and reported in Tables 1 and 2 can be ascribed to pleiotropic effects.

The recent findings that point to a primary and direct role of GUN1 in plastid RNA metabolism imply that the protein stimulates NEP activity and alters editing levels of a few NEP-dependent transcripts [12-16] and offer a novel perspective on GUN1 activity. In particular, 
the decreased accumulation of NEP-dependent transcripts, i.e., transcripts encoding mainly rRNA, tRNA, and housekeeping proteins, and the reduced editing levels of some of them observed in gun 1 seedlings upon either NF or Lin treatments, straightforwardly explain the additive effects observed in gun1-containing double mutants with defects in (i) plastid transcription, (ii) plastid transcript maturation and editing, and (iii) plastid translation. Moreover, the reduced accumulation of NEP-dependent $y c f 1$ transcripts [14], which code for the Tic214 subunit of the 1-MDa TIC (translocon at the inner envelope membrane of chloroplasts) complex involved in protein import into the stroma [52], could explain the enhanced/altered phenotypes of the double mutants gun1 tic40-4, gun1 ppi2, gun1 cphsc70-1, and gun1 clpc1-1, all of which are defective in plastid protein import. Similarly, the albino-seedling lethal phenotype of gun 1 ftsh $2-3$ and the severely variegated cotyledons typical of gun 1 ftsh $5-3$ could be due to the concomitant alteration of the thylakoid-associated heteromeric metalloprotease $\mathrm{FtsH}$ and the stromal Clp protease.

With respect to suppressor phenotypes, gene expression analysis has revealed that the introduction of $g u n 1$ into plants carrying the $s g 1$ genetic background partially rectifies the imbalance in the expression of chloroplast-related genes caused by the $s g 1$ mutation [38]. For example, the gun1 sg1 double mutant shows increased expression of $R b c L$ and $a c c D$ (both of which are expressed at very low levels in sg1) and much reduced expression of $r p o B$, relative to that in $s g 1$. Therefore, it seems that $g u n 1$ can partially correct the imbalance in levels of chloroplast-related genes in $s g 1$, thereby suppressing the deleterious phenotypes. Similarly, the increased accumulation of PRPS1 protein observed in the leaky prps1-1 mutant in the absence of the GUN1 protein (gun1 prps1-1; [17]) could be related to the lack of upregulation and editing of $C l p P 1$ transcripts encoding a subunit of the major plastid stromal protease. As a consequence, PRPS1 may be degraded less efficiently $[17,51]$. The suppression of the msl2 msl3 double mutant phenotype seen in gun 1 msl2 msl3 seedlings is more difficult to explain [48]. Certainly, GUN1-mediated retrograde communication is only one of the many regulatory pathways and feedback loops that govern dynamic cell identity decision-making at the plant shoot apex. It may be speculated that the absence of this communication still permits proper leaf differentiation, even in the presence of plastid dysfunctions in the shoot apex.

This large collection of genetic and molecular data related to GUN1 function can now be integrated into a model, which is based on the following lines of evidence (Figure 2):

a. GUN1 is present in very low amounts as long as chloroplast biogenesis proceeds normally, i.e., in the absence of stresses/dysfunction of developing plastids. As a matter of fact, the gun 1 mutant is hardly distinguishable from wild-type plants under optimal chloroplast biogenesis conditions (Figure 2a).

b. GUN1 protein levels increase when stresses and/or alterations of plastid functions occur during chloroplast biogenesis. Under these conditions, NEP activity is favored relative to PEP in the developing chloroplasts. This, together with the ensuing retrograde inhibition of photosynthesis-associated nuclear gene (PhANGs) expression, results in pale cotyledons and/or leaves in the best-case scenario. Therefore, the prevention of photo-oxidative damage seems to prevail over the optimal organization of the photosynthetic apparatus and its capacity for light absorption (Figure $2 b$ ).

c. Lack of GUN1 disables, at least partially, retrograde signaling and its repressive influence on PhANGs and causes major alterations in plastid RNA metabolism, including reduced NEP activity and changes in editing levels of RNAs encoding subunits of the ATP-dependent Clp protease, the NDH complex, the ribosomes, photosystem II, and the core of the PEP enzyme (Figure 2c). When the gun1 mutation is introgressed into genetic backgrounds with defects in either the plastid protein homeostasis machinery (see as examples sca3-1, sg1, prpl11-1, prps1-1, ftsh5-3, prin2-1, bpg2-2, ftsh1-1; for further details, refer to Table 1), sugar sensing (sicy-192; for further details, refer to Table 2), or plastid osmosis ( $m s l 2 \mathrm{msl} 3$; for further details, refer to Table 2), the corresponding higher-order mutants show a range of phenotypes. (i) In most cases, an exacerbated phenotype is observed, as a consequence of the fact that $g u n 1$-associated alterations 
are added to the impairments caused by the original mutant backgrounds as, for instance, in the case of sca3-1 gun1-102, prpl11-1 gun1-102, ftsh5-3 gun1-102 (for further details, see Table 1). (ii) In a few cases, no additive phenotype is detected, either because GUN1 activity is not required under that specific plastid perturbation, or is rather limited, as in the case of prin2-1 gun1-1, bpg2-2 gun1-101, ftsh1-1 gun1-102 (for further details, see Table 1). (iii) In a small minority of cases, a suppressor phenotype is observed as a consequence of the ability of gun1-associated alterations to mitigate the imbalances caused by the initial mutant backgrounds. This is the case of sg1 gun1-1 and prps1-1 gun1-102 double mutants and msl2 msl3 gun1-9 triple mutant.

Overall, GUN1 seems to modulate photosynthetic efficiency in cotyledons and leaves to minimize the consequences of malfunctions in developing chloroplasts, primarily with a view to preventing, or at least reducing, photo-oxidative damage.

a) wild type

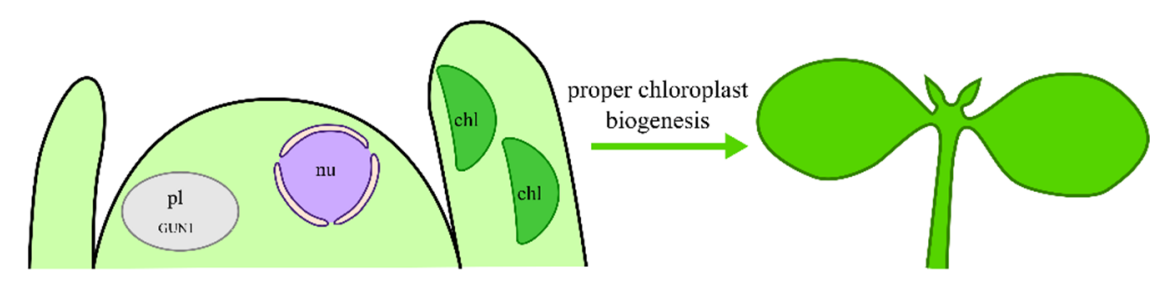

b) single mutants

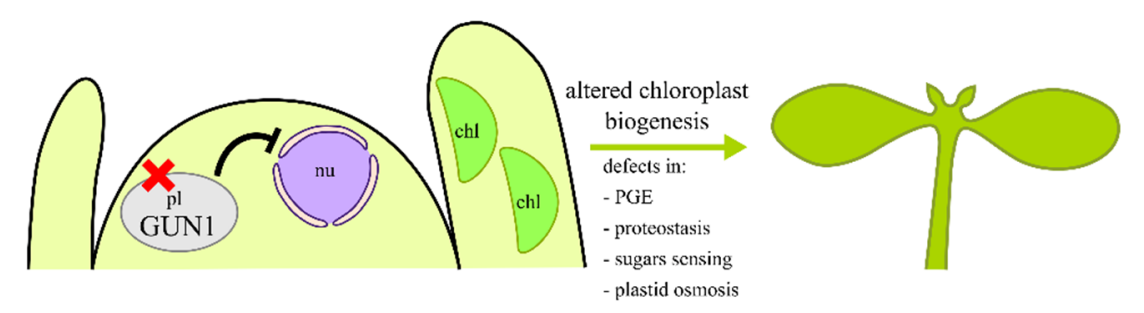

c) gunl-containing higher-order mutants

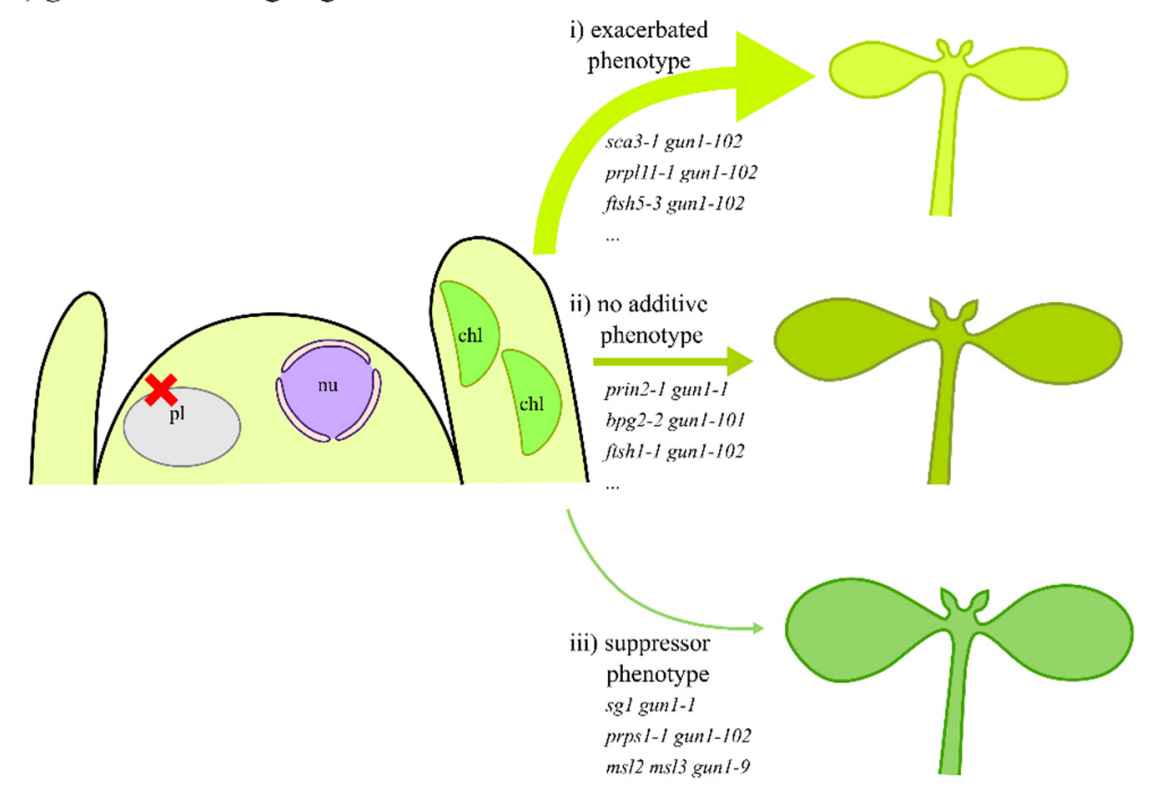

Figure 2. Schematic overview of the role of GUN1 protein during the early stages of chloroplast biogenesis. (a) Under optimal conditions, i.e., environmental and genetic conditions, the abundance of the GUN1 protein is rather low, and no GUN1-dependent negative retrograde signal is sent from the 
developing chloroplasts to the nucleus to downregulate the expression of PhANGs. As a result, proper chloroplast biogenesis occurs in cotyledons and leaves. (b) Under conditions that alter plastid activity, i.e., genetic defects that impair plastid gene expression (PGE), plastid protein homeostasis (proteostasis), sugar sensing, and plastid osmosis, the abundance of GUN1 protein increases in developing chloroplasts. As a consequence, NEP activity is favored over PEP, changes in plastid RNA editing levels take place, and a GUN1-dependent negative signal reaches the nucleus and reduces expression of PhANGs. In this scenario, seedlings show defects in chloroplast development, photosynthetic performance, and growth. (c) The importance of the GUN1 protein in chloroplast biogenesis becomes evident when the gun 1 mutation is introgressed into Arabidopsis mutants with defects in PGE, proteostasis, sugar sensing, and maintenance of plastid osmosis. Under these conditions, chloroplast biogenesis is altered, and the GUN1-dependent negative retrograde signal is absent. These conditions, in most of the analyzed cases (20 out of $31,64.5 \%$ ), result in exacerbated phenotypes, characterized by a marked reduction in leaf pigmentation and reduced photosynthetic performance and growth. Only in few cases (25.8\%), the lack of GUN1 protein fails to cause additive phenotypic effects, while in the remaining three cases (9.7\%), lack of GUN1 suppresses the mutant phenotypes. pl, proplastid; nu, nucleus; chl, chloroplast.

\section{Conclusions and Open Questions}

Over the past decade, several labs worldwide have collected important pieces of genetic and molecular information concerning the role of GUN1 during the early stages of chloroplast biogenesis. The very recent data on the involvement of GUN1 in plastid RNA metabolism obtained in our lab, almost concomitantly with the labs of Joanne Chory and Enrique Lopez-Juez, allow us to integrate all the information now available into a unified model, which is schematically depicted in Figure 2 [12-16]. As yet, little can be said about how GUN1 is recruited to modulate transcript accumulation and editing under conditions that trigger retrograde communication. Furthermore, the molecular mechanism(s) that link(s) plastid RNA metabolism to retrograde signaling deserve(s) further study. The changes in editing levels of transcripts encoding subunits of the NDH complex prompt the speculation that alteration of NDH activity could affect the redox state of plastids, thereby triggering retrograde communication. In addition, modification of Clp protease activity, as a consequence of a GUN1-dependent influence on $\operatorname{clpP}$ RNA metabolism, could be at the basis of the unfolded protein response signaling pathway [39,53-55]. Similarly, altered expression of the plastid gene ycf1 could provide the connection between plastid protein import, cytosolic folding stress, and plastid precursor protein-mediated retrograde communication [14,44]. Further analyses of GUN1 and its involvement in plastid RNA metabolism will provide important clues to the molecular mechanisms at the root of the coordination of plastid-nucleus gene expression. In this context, we suggest the use of GUN1 chimeras expressed under the control of the wild-type GUN1 promoter-which can be obtained by the recently developed CRISPR/Cas9-mediated gene targeting approach [56] — to resolve remaining ambiguities in GUN1 function—introduced, most probably, by the use of GUN1 over-expressing lines for molecular studies. This strategy, designed in several labs to boost the very low abundance of the GUN1, might have led to the identification of interacting partners that are not essential for its function, as a consequence of the rather sticky nature of the protein, as highlighted by the identification of several protein interactors [57]. In the end, GUN1 may turn out to an "almost" typical plastid PPR protein, as indicated by its involvement in RNA metabolism.

Author Contributions: L.T. and N.J. have drafted the manuscript. L.T. organized Tables 1 and 2 while N.J. took care of Figures 1 and 2. P.P. supervised the entire work and finalized the manuscript. All authors have read and agreed to the published version of the manuscript.

Funding: This research was funded by MUR-Ministero dell'Università e della Ricerca, grant number PRIN-2017 2017FBS8YN.

Acknowledgments: We apologize to the authors who did not get their work discussed in this manuscript due to space limitations. We are grateful to Paul Hardy for critical reading of the manuscript.

Conflicts of Interest: The authors declare no conflict of interest. 


\section{References}

1. Susek, R.E.; Ausubel, F.M.; Chory, J. Signal transduction mutants of arabidopsis uncouple nuclear CAB and RBCS gene expression from chloroplast development. Cell 1993, 74, 787-799. [CrossRef]

2. Koussevitzky, S.; Nott, A.; Mockler, T.C.; Hong, F.; Sachetto-Martins, G.; Surpin, M.; Lim, J.; Mittler, R.; Chory, J. Signals from Chloroplasts Converge to Regulate Nuclear Gene Expression. Science 2007, 316, 715-719. [CrossRef]

3. Bramley, P.M. Inhibition of carotenoid biosynthesis. In Carotenoids in Photosynthesis; Springer: Berlin/Heidelberg, Germany, 1993; pp. 127-159.

4. Mulo, P.; Pursiheimo, S.; Hou, C.X.; Tyystjärvi, T.; Aro, E.M. Multiple effects of antibiotics on chloroplast and nuclear gene expression. Funct. Plant Biol. 2003, 30, 1097-1103. [CrossRef] [PubMed]

5. Gray, J.C.; Sullivan, J.A.; Wang, J.H.; Jerome, C.A.; MacLean, D.; Allen, J.F.; Horner, D.S.; Howe, C.J.; Lopez-Juez, E.; Herrmann, R.G.; et al. Coordination of plastid and nuclear gene expression. Philos. Trans. R. Soc. B Biol. Sci. 2003, 358, 135-145. [CrossRef]

6. Mathews, D.E.; Durbin, R.D. Tagetitoxin inhibits RNA synthesis directed by RNA polymerases from chloroplasts and Escherichia coli. J. Biol. Chem. 1990, 265, 493-498.

7. Rapp, J.C.; Mullet, J.E. Chloroplast transcription is required to express the nuclear genes rbcS and cab. Plastid DNA copy number is regulated independently. Plant Mol. Biol. 1991, 17, 813-823. [CrossRef] [PubMed]

8. Allison, L.A. The role of sigma factors in plastid transcription. Biochimie 2000, 82, 537-548. [CrossRef]

9. Lysenko, E.A. Plant sigma factors and their role in plastid transcription. Plant Cell Rep. 2007, 26, 845-859. [CrossRef] [PubMed]

10. Chi, W.; He, B.; Mao, J.; Jiang, J.; Zhang, L. Plastid sigma factors: Their individual functions and regulation in transcription. Biochim. Biophys. Acta Bioenerg. 2015, 1847, 770-778. [CrossRef] [PubMed]

11. Woodson, J.D.; Perez-Ruiz, J.M.; Schmitz, R.J.; Ecker, J.R.; Chory, J. Sigma factor-mediated plastid retrograde signals control nuclear gene expression. Plant J. 2013, 73, 1-13. [CrossRef]

12. Zhao, X.; Huang, J.; Chory, J. GUN1 interacts with MORF2 to regulate plastid RNA editing during retrograde signaling. Proc. Natl. Acad. Sci. USA 2019, 116, 10162-10167. [CrossRef] [PubMed]

13. Loudya, N.; Okunola, T.; He, J.; Jarvis, P.; López-Juez, E. Retrograde signalling in a virescent mutant triggers an anterograde delay of chloroplast biogenesis that requires GUN1 and is essential for survival. Philos. Trans. R. Soc. B Biol. Sci. 2020, 375, 20190400. [CrossRef] [PubMed]

14. Tadini, L.; Peracchio, C.; Trotta, A.; Colombo, M.; Mancini, I.; Jeran, N.; Costa, A.; Faoro, F.; Marsoni, M.; Vannini, C.; et al. GUN1 influences the accumulation of NEP-dependent transcripts and chloroplast protein import in Arabidopsis cotyledons upon perturbation of chloroplast protein homeostasis. Plant J. 2020, 101, 1198-1220. [CrossRef] [PubMed]

15. Tadini, L.; Jeran, N.; Peracchio, C.; Masiero, S.; Colombo, M.; Pesaresi, P. The plastid transcription machinery and its coordination with the expression of nuclear genome: Plastid-Encoded Polymerase, Nuclear-Encoded Polymerase and the Genomes Uncoupled 1-mediated retrograde communication. Philos. Trans. R. Soc. B Biol. Sci. 2020, 375, 20190399. [CrossRef] [PubMed]

16. Zhao, X.; Huang, J.; Chory, J. Unraveling the Linkage between Retrograde Signaling and RNA Metabolism in Plants. Trends Plant Sci. 2020, 25, 141-147. [CrossRef] [PubMed]

17. Tadini, L.; Pesaresi, P.; Kleine, T.; Rossi, F.; Guljamow, A.; Sommer, F.; Mühlhaus, T.; Schroda, M.; Masiero, S.; Pribil, M.; et al. GUN1 Controls Accumulation of the Plastid Ribosomal Protein S1 at the Protein Level and Interacts with Proteins Involved in Plastid Protein Homeostasis. Plant Physiol. 2016, 170, 1817-1830. [CrossRef] [PubMed]

18. Allison, L.A.; Simon, L.D.; Maliga, P. Deletion of rpoB reveals a second distinct transcription system in plastids of higher plants. EMBO J. 1996, 15, 2802-2809. [CrossRef]

19. Hajdukiewicz, P.T.J.; Allison, L.A.; Maliga, P. The two RNA polymerases encoded by the nuclear and the plastid compartments transcribe distinct groups of genes in tobacco plastids. EMBO J. 1997, 16, 4041-4048. [CrossRef]

20. De Santis-Maciossek, G.; Kofer, W.; Bock, A.; Schoch, S.; Maier, R.M.; Wanner, G.; Rüdiger, W.; Koop, H.U.; Herrmann, R.G. Targeted disruption of the plastid RNA polymerase genes rpoA, B and C1: Molecular biology, biochemistry and ultrastructure. Plant J. 1999, 18, 477-489. [CrossRef]

21. Lerbs-Mache, S. Function of plastid sigma factors in higher plants: Regulation of gene expression or just preservation of constitutive transcription? Plant Mol. Biol. 2011, 76, 235-249. [CrossRef] 
22. Steiner, S.; Schroter, Y.; Pfalz, J.; Pfannschmidt, T. Identification of Essential Subunits in the Plastid-Encoded RNA Polymerase Complex Reveals Building Blocks for Proper Plastid Development. Plant Physiol. 2011, 157, 1043-1055. [CrossRef] [PubMed]

23. Kindgren, P.; Kremnev, D.; Blanco, N.E.; de Dios Barajas López, J.; Fernández, A.P.; Tellgren-Roth, C.; Small, I.; Strand, A. The plastid redox insensitive 2 mutant of Arabidopsis is impaired in PEP activity and high light-dependent plastid redox signalling to the nucleus. Plant J. 2012, 70, 279-291. [CrossRef] [PubMed]

24. Díaz, M.G.; Hernández-Verdeja, T.; Kremnev, D.; Crawford, T.; Dubreuil, C.; Strand, Å. Redox regulation of PEP activity during seedling establishment in Arabidopsis thaliana. Nat. Commun. 2018, 9. [CrossRef]

25. Wu, H.; Zhang, L. The PPR protein PDM1 is involved in the processing of rpoA pre-mRNA in Arabidopsis thaliana. Chin. Sci. Bull. 2010, 55, 3485-3489. [CrossRef]

26. Schweer, J.; Geimer, S.; Meurer, J.; Link, G. Arabidopsis mutants carrying chimeric sigma factor genes reveal regulatory determinants for plastid gene expression. Plant Cell Physiol. 2009, 50, 1382-1386. [CrossRef]

27. Pfalz, J.; Liere, K.; Kandlbinder, A.; Dietz, K.J.; Oelmüller, R. pTAC2, -6, and -12 are components of the transcriptionally active plastid chromosome that are required for plastid gene expression. Plant Cell 2006, 18, 176-197. [CrossRef]

28. Pyo, Y.J.; Kwon, K.C.; Kim, A.; Cho, M.H. Seedling lethal1, a pentatricopeptide repeat protein lacking an E/E+ or DYW domain in Arabidopsis, is involved in plastid gene expression and early chloroplast development. Plant Physiol. 2013, 163, 1844-1858. [CrossRef]

29. Myouga, F.; Hosoda, C.; Umezawa, T.; Iizumi, H.; Kuromori, T.; Motohashi, R.; Shono, Y.; Nagata, N.; Ikeuchi, M.; Shinozaki, K. A heterocomplex of iron superoxide dismutases defends chloroplast nucleoids against oxidative stress and is essential for chloroplast development in arabidopsis. Plant Cell 2008, 20, 3148-3162. [CrossRef]

30. Zhou, W.; Cheng, Y.; Yap, A.; Chateigner-Boutin, A.L.; Delannoy, E.; Hammani, K.; Small, I.; Huang, J. The Arabidopsis gene YS1 encoding a DYW protein is required for editing of rpoB transcripts and the rapid development of chloroplasts during early growth. Plant J. 2009, 58, 82-96. [CrossRef]

31. Ramos-Vega, M.; Guevara-García, A.; Llamas, E.; Sánchez-León, N.; Olmedo-Monfil, V.; Vielle-Calzada, J.P.; León, P. Functional analysis of the Arabidopsis thaliana CHLOROPLAST BIOGENESIS 19 pentatricopeptide repeat editing protein. New Phytol. 2015, 208, 430-441. [CrossRef]

32. Small, I.D.; Schallenberg-Rüdinger, M.; Takenaka, M.; Mireau, H.; Ostersetzer-Biran, O. Plant organellar RNA editing: What 30 years of research has revealed. Plant J. 2020, 101, 1040-1056. [CrossRef]

33. Kakizaki, T.; Yazu, F.; Nakayama, K.; Ito-Inaba, Y.; Inaba, T. Plastid signalling under multiple conditions is accompanied by a common defect in RNA editing in plastids. J. Exp. Bot. 2012, 63, 251-260. [CrossRef] [PubMed]

34. Yu, Q.B.; Jiang, Y.; Chong, K.; Yang, Z.N. AtECB2, a pentatricopeptide repeat protein, is required for chloroplast transcript accd rna editing and early chloroplast biogenesis in arabidopsis thaliana. Plant J. 2009, 59, 1011-1023. [CrossRef] [PubMed]

35. Tseng, C.C.; Sung, T.Y.; Li, Y.C.; Hsu, S.J.; Lin, C.L.; Hsieh, M.H. Editing of accD and ndhF chloroplast transcripts is partially affected in the Arabidopsis vanilla cream1 mutant. Plant Mol. Biol. 2010, 73, 309-323. [CrossRef] [PubMed]

36. Takenaka, M.; Zehrmann, A.; Verbitskiy, D.; Kugelmann, M.; Härtel, B.; Brennicke, A. Multiple organellar RNA editing factor (MORF) family proteins are required for RNA editing in mitochondria and plastids of plants. Proc. Natl. Acad. Sci. USA 2012, 109, 5104-5109. [CrossRef] [PubMed]

37. Chateigner-Boutin, A.L.; Ramos-Vega, M.; Guevara-García, A.; Andrés, C.; Gutiérrez-Nava, M.D.L.L.; Cantero, A.; Delannoy, E.; Jiménez, L.F.; Lurin, C.; Small, I.; et al. CLB19, a pentatricopeptide repeat protein required for editing of rpoA and clpP chloroplast transcripts. Plant J. 2008, 56, 590-602. [CrossRef] [PubMed]

38. Hu, Z.; Xu, F.; Guan, L.; Qian, P.; Liu, Y.; Zhang, H.; Huang, Y.; Hou, S. The tetratricopeptide repeat-containing protein slow green1 is required for chloroplast development in Arabidopsis. J. Exp. Bot. 2014, 65, 1111-1123. [CrossRef]

39. Llamas, E.; Pulido, P.; Rodriguez-Concepcion, M. Interference with plastome gene expression and Clp protease activity in Arabidopsis triggers a chloroplast unfolded protein response to restore protein homeostasis. PLoS Genet. 2017, 13, e1007022. [CrossRef]

40. Wang, J.; Xia, H.; Zhao, S.Z.; Hou, L.; Zhao, C.Z.; Ma, C.L.E.; Wang, X.J.; Li, P.C. A role of GUNs-Involved retrograde signaling in regulating Acetyl-CoA carboxylase 2 in Arabidopsis. Biochem. Biophys. Res. Commun. 2018, 505, 712-719. [CrossRef] 
41. Paieri, F.; Tadini, L.; Manavski, N.; Kleine, T.; Ferrari, R.; Morandini, P.; Pesaresi, P.; Meurer, J.; Leister, D. The DEAD-box RNA helicase RH50 is a 23S-4.5S rRNA maturation factor that functionally overlaps with the plastid signaling factor GUN1. Plant Physiol. 2018, 176, 634-648. [CrossRef]

42. Sun, X.; Xu, D.; Liu, Z.; Kleine, T.; Leister, D. Functional relationship between mTERF4 and GUN1 in retrograde signaling. J. Exp. Bot. 2016, 67, 3909-3924. [CrossRef] [PubMed]

43. Marino, G.; Naranjo, B.; Wang, J.; Penzler, J.F.; Kleine, T.; Leister, D. Relationship of GUN1 to FUG1 in chloroplast protein homeostasis. Plant J. 2019, 99, 521-535. [CrossRef] [PubMed]

44. Wu, G.Z.; Meyer, E.H.; Richter, A.S.; Schuster, M.; Ling, Q.; Schöttler, M.A.; Walther, D.; Zoschke, R.; Grimm, B.; Jarvis, R.P.; et al. Control of retrograde signalling by protein import and cytosolic folding stress. Nat. Plants 2019, 5, 525-538. [CrossRef] [PubMed]

45. Kato, Y.; Sakamoto, W. FtsH protease in the thylakoid membrane: Physiological functions and the regulation of protease activity. Front. Plant Sci. 2018, 9, 855. [CrossRef] [PubMed]

46. Vinti, G.; Hills, A.; Campbell, S.; Bowyer, J.R.; Mochizuki, N.; Chory, J.; López-Juez, E. Interactions between hy1 and gun mutants of Arabidopsis, and their implications for plastid/nuclear signalling. Plant J. 2008, 24, 883-894. [CrossRef]

47. Mochizuki, N.; Brusslan, J.A.; Larkin, R.; Nagatani, A.; Chory, J. Arabidopsis genomes uncoupled 5 (GUN5) mutant reveals the involvement of $\mathrm{Mg}$-chelatase $\mathrm{H}$ subunit in plastid-to-nucleus signal transduction. Proc. Natl. Acad. Sci. USA 2001, 98, 2053-2058. [CrossRef]

48. Wilson, M.E.; Mixdorf, M.; Berg, R.H.; Haswell, E.S. Plastid osmotic stress influences cell differentiation at the plant shoot apex. Development 2016, 143, 3382-3393. [CrossRef]

49. Maruta, T.; Miyazaki, N.; Nosaka, R.; Tanaka, H.; Padilla-Chacon, D.; Otori, K.; Kimura, A.; Tanabe, N.; Yoshimura, K.; Tamoi, M.; et al. A gain-of-function mutation of plastidic invertase alters nuclear gene expression with sucrose treatment partially via GENOMES UNCOUPLED1-mediated signaling. New Phytol. 2015, 206, 1013-1023. [CrossRef]

50. Tameshige, T.; Fujita, H.; Watanabe, K.; Toyokura, K.; Kondo, M.; Tatematsu, K.; Matsumoto, N.; Tsugeki, R.; Kawaguchi, M.; Nishimura, M.; et al. Pattern Dynamics in Adaxial-Abaxial Specific Gene Expression Are Modulated by a Plastid Retrograde Signal during Arabidopsis thaliana Leaf Development. PLoS Genet. 2013, 9, e1003655. [CrossRef]

51. Wu, G.Z.; Chalvin, C.; Hoelscher, M.; Meyer, E.H.; Wu, X.N.; Bock, R. Control of retrograde signaling by rapid turnover of GENOMES UNCOUPLED1. Plant Physiol. 2018, 176, 2472-2495. [CrossRef]

52. Kikuchi, S.; Bédard, J.; Hirano, M.; Hirabayashi, Y.; Oishi, M.; Imai, M.; Takase, M.; Ide, T.; Nakai, M. Uncovering the protein translocon at the chloroplast inner envelope membrane. Science 2013, 339, 571-574. [CrossRef]

53. Ramundo, S.; Rochaix, J.D. Chloroplast unfolded protein response, a new plastid stress signaling pathway? Plant Signal. Behav. 2014, 9, 1-3. [CrossRef]

54. Ramundo, S.; Casero, D.; Muhlhaus, T.; Hemme, D.; Sommer, F.; Crevecoeur, M.; Rahire, M.; Schroda, M.; Rusch, J.; Goodenough, U.; et al. Conditional Depletion of the Chlamydomonas Chloroplast ClpP Protease Activates Nuclear Genes Involved in Autophagy and Plastid Protein Quality Control. Plant Cell 2014, 26, 2201-2222. [CrossRef] [PubMed]

55. Perlaza, K.; Toutkoushian, H.; Boone, M.; Lam, M.; Iwai, M.; Jonikas, M.C.; Walter, P.; Ramundo, S. The mars1 kinase confers photoprotection through signaling in the chloroplast unfolded protein response. eLife 2019, 8. [CrossRef]

56. Miki, D.; Zhang, W.; Zeng, W.; Feng, Z.; Zhu, J.K. CRISPR/Cas9-mediated gene targeting in Arabidopsis using sequential transformation. Nat. Commun. 2018, 9. [CrossRef]

57. Colombo, M.; Tadini, L.; Peracchio, C.; Ferrari, R.; Pesaresi, P. GUN1, a Jack-Of-All-Trades in Chloroplast Protein Homeostasis and Signaling. Front. Plant. Sci. 2016, 7. [CrossRef] [PubMed]

Publisher's Note: MDPI stays neutral with regard to jurisdictional claims in published maps and institutional affiliations. 